\title{
Cytotoxicity of Endophytes of Calotropis procera, Solanum nigrum and Forsskaolea tenacissima
}

\author{
Hany G. Attia ${ }^{1}$, Mohamed Aleraky ${ }^{2,3}$, Mahmoud Youns ${ }^{4}$, Randa Abdou \\ ${ }^{1}$ Department of Pharmacognosy, College of Pharmacy, Najran University, Najran, SAUDI ARABIA. \\ 2Department of Clinical Pathology, College of Medicine, Najran University, Najran, SAUDI ARABIA. \\ ${ }^{3}$ Department of Clinical Pathology, College of Medicine, New Demiatta University Hospital, Alazhar University, EGYPT. \\ ${ }^{4}$ Department of Biochemistry and Molecular Biology, Faculty of Pharmacy, Helwan University, Cairo, EGYPT. \\ ${ }^{5}$ Department of Pharmacognosy, Faculty of Pharmacy, Umm Al-Qura University, Makkah, SAUDI ARABIA. \\ ${ }^{6}$ Department of Pharmacognosy, Faculty of Pharmacy, Helwan University, Cairo, EGYPT.
}

\begin{abstract}
Aim: Due to the urgent need for anticancer agents, investigation of endophytes of medicinal plants growing in special environments is considered a promising approach for the search of bioactive natural products. Materials and Methods: The ethyl acetate extracts of the cultures of twelve endophytic fungi were isolated from the medicinal plants Calotropis procera fam Apocynaceae, Solanum nigrum fam Solanaceae and Forsskaolea tenacissima fam Urticaceae growing in one of the richest areas of plant biodiversity in Saudi Arabia, Najran. All isolated and identified endophytic fungi were subjected to preliminary screening assays for cytotoxic activity. Results: Four of the isolated endophytic fungi (Cladosporium herbarum (1), Hortaea werneckii (2), Penicillium solitum (3) and Eurotium chevalieri (4)) exerted cytotoxic activity against HepG2, T-47D, HCT-116 and RAW 264.7 in the MTT cell viability assay. The highest cytotoxic effects were observed for the extract of Penicillium solitum on HepG2 and HCT-116 cell lines with $\mathrm{IC}_{50}$ values of $13 \mu \mathrm{g} / \mathrm{ml}$ and $42 \mu \mathrm{g} / \mathrm{ml}$, respectively. All endophytic extracts showed rather weak cytotoxic effects against RAW 264.7 cell line with $I_{50}$ values of 357, 347, 345 and $420 \mu \mathrm{g} / \mathrm{ml}$ for extracts of endophytes 1,2,3 and 4, respectively. High cytotoxic effects were observed for the extracts of endophytes 1, 2 and 3 against T-47D cell line with $I_{50}$ values of 78,69 and $94 \mu \mathrm{g} / \mathrm{ml}$, respectively. Conclusion: These bioactive endophytes represent candidates for future investigation of bioactive metabolites with potential medical applications.
\end{abstract}

Key words: Endophytes, Cytotoxic activity, Medicinal plants, Calotropis procera, Solanum nigrum, Forsskaolea tenacissima.

\section{INTRODUCTION}

Cancer is a life-threatening disease that is continuously spreading in many countries around the world. According to previously conducted studies, an increase in the incidence of cancer cases has been observed in Saudi Arabia and is expected to grow in the future. A six to ten-fold increase in cancer cases compared to the incidence recorded in 2004 is statistically anticipated by the year $2030 .{ }^{1}$ Therefore, there is an urgent need for new anticancer agents to overcome the growing incidence of cancer.

Many years ago plants started to represent a rich source of natural products with biodiverse activities. Later on, even the microorganisms inhabiting these plants, the endophytes, provided many biologically active natural compounds.

Several studies reported the detection of endophytes in different plant species which indicates the wide distribution of endophytes in the plant kingdom. ${ }^{2}$ As each plant might contain several new endophytic species, it has been concluded that endophytes are a rich source of new bioactive natural products. ${ }^{3}$ To identify plants with promising bioactive endophytes, it is advisable to select plants growing in unique
Submission Date: 23-12-2020; Revision Date: 23-04-2021; Accepted Date: 18-06-2021

DOI: 10.5530/ijper.55.3.161 Correspondence: Dr. Randa Abdou Department of Pharmacognosy, Faculty of Pharmacy,

Umm Al-Qura University, 24231 Makkah, KSA.

Phone no: +966 546132281 Email id: rfabdou@uqu.edu.sa

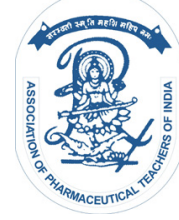

www.ijper.org 
environments as they are expected to have special survival strategies. Furthermore, plants used in traditional medicines are also considered promising sources of bioactive endophytes. It is also recommended to search for plants growing in biodiverse environmental conditions which are expected to contain a high diversity of endophytes as well. ${ }^{4}$ Most of these criteria can be fulfilled by investigating bioactive medicinal plants growing in the Najran region of Saudi Arabia which is considered as one of the richest areas of plants and natural biodiversity. ${ }^{5}$ The medicinal plant Calotropis procera growing in Brazil has been reported to exert antitumor activities, ${ }^{6}$ while Solanum nigrum cultivated in India was found to exert anti-inflammatory and antimicrobial activities ${ }^{7}$ and Forsskaolea tenacissima growing in Egypt showed antiviral, antibacterial and cytotoxic effects. $^{8}$

However, minimal studies have been performed on plants in the highly biodiverse region of Najran. Accordingly, we present in this study the investigation of the endophytes of the medicinal plants Calotropis procera, Solanum nigrum and Forsskaolea tenacissima growing in this region and their anticancer activity. This investigation shows that this region represents a promising source of bioactive endophytes and is the first step in the search for new anticancer agents required to meet community needs.

\section{MATERIALS AND METHODS}

\section{Collection of plants}

Plant materials were collected from the Najran region during February and March 2015. Samples were selected based on healthy exterior features. Freshly collected, healthy plant roots were stored in plastic bags in a cooler with ice during collection until processing for endophyte isolation. The plant species were identified by Dr. Hany Gouda, Department of Pharmacognosy, College of Pharmacy, Najran University, Saudi Arabia, and Prof. Dr. Mohammed Ammar, Applied Medical Science College, Najran University, Saudi Arabia, and maintained for further processing.

\section{Isolation of Endophytic fungi}

Samples were rinsed with water to remove soil and debris. Any dead plant tissue was removed from all plant parts and the remaining plant roots were dissected into tissues corresponding to the root crown before surface sterilization.

Isolation of endophytic fungi from plant parts was performed according to the previously published literature data. ${ }^{9-11}$ Each sample was surface sterilized with 70\% ethanol for $1 \mathrm{~min}$ and immersed in sodium hypochlorite $(\mathrm{NaOCl})$ solution for at least $30 \mathrm{sec}$. Sterile distilled water was used to rinse the samples for one minute and then allowed to surface dry on filter paper. After proper drying, four pieces of roots were inoculated in potato dextrose agar (PDA) plates amended with Streptomycin (40-50 mg/l) and incubated at $28 \pm 1^{\circ} \mathrm{C}$ for 5 to 7 days. The plant fragments were examined for the growth of endophytic fungi once every $24 \mathrm{hr}$. Hyphal tips were quickly transferred into PDA slants and maintained at $4^{\circ} \mathrm{C}$. The fungal isolates were recognized by identifying their conidiophore structures and morphological characters using approved identification manuals. ${ }^{12}$ Pure colonies were preserved in PDA slants at $4^{\circ} \mathrm{C}$ with proper labeling and were sub-cultured from time to time. Colonization frequency $(\mathrm{CF} \%)$ was calculated by dividing the number of individual fungi recorded by the total number of segments screened and multiplying the result with 100 according to the following equation: ${ }^{13}$

$\mathrm{CF} \%=$ No. of individual fungi recorded $/$ Total no. of segments screened $\times 100$

\section{Mass cultivation of endophytic fungi}

Potato dextrose broth was used to mass cultivate the selected endophytic fungi (Hortaea werneckii, Penicillium solitum, Eurotium chevalieri and Cladosporium herbarum), by placing the agar discs of each actively growing pure culture ( $3 \mathrm{~mm}$ in diameter) in Erlenmeyer flasks $(250 \mathrm{ml})$ containing $100 \mathrm{ml}$ of the medium. The flasks were incubated for three weeks at $28^{\circ} \mathrm{C}$. After three weeks of incubation, the cultures' filtrates with mycelia were taken out for further extraction.

\section{Preparation of extracts of endophytic fungi}

Following mass cultivation of endophytic fungi, ethyl acetate was used to extract the fungal metabolites from different cultures of mixed cultural filtrates and mycelial mats. Equivalent volumes of the solvent and filtrate were added in a separating funnel and shaken vigorously for ten minutes. The solution in the separating funnel was then allowed to stand, the cell mass was isolated and the solvent collected. The resultant crude extracts were dried and collected after evaporating ethyl acetate in a vacuum evaporator using $\mathrm{MgSO}_{4}$ to yield the crude extracts of $123 \mathrm{mg}, 61 \mathrm{mg}, 47 \mathrm{mg}$ and $38 \mathrm{mg}$ for Hortaea werneckii, Penicillium solitum, Eurotium chevalieri and Cladosporium herbarum, respectively. ${ }^{14}$ The crude extracts (samples 1-4) of all endophytic fungi under investigation Cladosporium berbarum (1), Hortaea werneckii (2), Penicillium solitum (3) and Eurotium chevalieri 
(4), respectively were then subjected to a cytotoxic assay against HepG2, HCT-116, T-47D and RAW 264.7 cell lines using the MTT Cell Viability assay.

\section{Investigation of anticancer activity}

Cytotoxic activity of endophytic samples was examined by using human ductal breast epithelial tumour cells (T47D), human hepatocarcinoma cell line (HepG2), raw murine macrophages (RAW 264.7) and human colorectal carcinoma cells (HCT-116) purchased from ATCC, USA. Cells were routinely cultured in Dulbecco's Modified Eagle's Medium (DMEM) for HepG2 and T47D. RPMI-1640 was used for RAW 264.7 cells and McCoy's 5a Medium Modified for HCT-116 which were enriched with $10 \%$ fetal bovine serum, 100 units $/ \mathrm{ml}$ streptomycin sulphate, $250 \mathrm{ng} / \mathrm{ml}$ amphotericin B and $2 \mathrm{mM}$ L-glutamine containing 100 units $/ \mathrm{ml}$ penicillin $\mathrm{G}$ sodium. Cells were sustained at sub-confluency at $37^{\circ} \mathrm{C}$ in humidified air $\left(5 \% \mathrm{CO}_{2}\right)$. For sub-culturing, after trypsin/EDTA treatment at $37^{\circ} \mathrm{C}$, monolayer cells were harvested, except for RAW 264.7 cells, which were accumulated by scraping. When confluency reached $75 \%$, the cells were utilised. Samples under investigation were dissolved in dimethyl sulphoxide (DMSO) and diluted thousand times. The cell culture materials were purchased from Cambrex BioScience, Copenhagen, Denmark. All other chemicals were obtained from Sigma-Aldrich, USA. Experiments were repeated four times. The cytotoxic effect of the endophytic samples was evaluated against HepG2, T-47D, HCT-116 and RAW 264.7 cells by employing the MTT Cell Viability Assay according to the literature. ${ }^{15}$ MTT (3-[4,5-dimethylthiazole-2-yl]-2,5-diphenyltetrazolium bromide) assay is based on the capability of active mitochondrial dehydrogenase enzyme of active cells to cleave the tetrazolium rings of the yellow MTT and produce a dark blue insoluble formazan crystal. The extent of MTT reduction was quantified by measuring the absorbance at $570 \mathrm{~nm}$, as previously described. ${ }^{15}$

A flat-bottom 96-well microplate was used to plate the cells $\left(0.5 \times 10^{5}\right.$ cells/ well $)$, in serum-free media and treated with different concentrations of the endophytic samples for $24 \mathrm{hr}$ at $37^{\circ} \mathrm{C}$, in a humidified atmosphere with $5 \% \mathrm{CO}_{2}$. After incubation, the media were separated and $40 \mu \mathrm{l}$ MTT solution/well was added and incubated for an additional $4 \mathrm{hr}$. By adding $180 \mu \mathrm{l}$ of acidified isopropanol/well, the MT'T crystals were solubilized and the plate was agitated at room temperature, followed by determination of the absorbance at $570 \mathrm{~nm}$ using microplate ELISA reader. Data were expressed as the percentage of relative viability according to the literature. ${ }^{15,16}$

\section{RESULTS}

Twelve fungal strains were isolated from the root samples of the medicinal plants Solanum nigrum; Forsskaolea tenacissima and Calotropis procera (Table 1).

They belong to families Solanaceae, Urticaceae and Apocynaceae (Table 1). Ten fungal species of the isolated endophytes were found to belong to Ascomycota and one to Basidiomycota. Identification of these fungal strains was carried out using the standard protocol based on their cultural and microscopic properties ${ }^{12}$ and was re-confirmed by the Microloge system (Biolog, Inc., Hayward, CA) at the National Research

Table 1: Characterization and frequencies of endophytic fungi of Calotropis procera, Solanum nigrum and
Forsskaolea tenacissima


Central Lab., GSFMO, KSA. ${ }^{17}$ Different frequencies of fungi were calculated (Table 1).

Based on the anticancer screening assay performed on the obtained endophytic extracts four fungal endophytes were selected for investigation of their extracts for anticancer activity against the cancer cell lines HepG2, T-47D, HCT-116 and RAW 264.7.

Using the MTT assay, the effect of samples 1-4 of the selected 4 endophytic extracts (H. werneckii, P. solitum, E. chevalieri and $C$. herbarum extracts) on the proliferation of four cancer cell lines HepG2, T-47D, HCT-116 and RAW 264.7 was studied after 24 hr of incubation. As shown in Figures 1-4, the samples showed variable cytotoxicity on each cell line.

As illustrated in Figure 1, sample 2 (P. solitum extract) exerted significantly high cytotoxicity against HepG2 cell line with a very low $\mathrm{IC}_{50}$ value of $13 \mu \mathrm{g} / \mathrm{ml}$. Samples 3 and 4 of the endophytes E. chevalieri and $C$. herbarum, on the contrary, exerted lower cytotoxic activity on HepG2 cells compared to sample 2 which was concluded from the moderately high $\mathrm{IC}_{50}$ values of 100 and $202 \mu \mathrm{g} / \mathrm{ml}$ obtained for these samples, respectively (Figure 1).

Sample 1 (H. werneckii extract) showed the lowest cytotoxic effect against HepG2 cells which was concluded from its high $\mathrm{IC}_{50}$ value $(367 \mu \mathrm{g} / \mathrm{ml})$.

As for the cytotoxic activity exerted on T-47D cells, samples 1, 2 and 3 were highly cytotoxic by exhibiting $\mathrm{IC}_{50}$ values of 78, 69 and $94 \mu \mathrm{g} / \mathrm{ml}$ respectively. Sample 4 (C. herbarum extract) exerted the weakest cytotoxic effect on T-47D cells by demonstrating the highest calculated $\mathrm{IC}_{50}$ value $(196 \mu \mathrm{g} / \mathrm{ml})$ as shown in (Figure 2$)$.

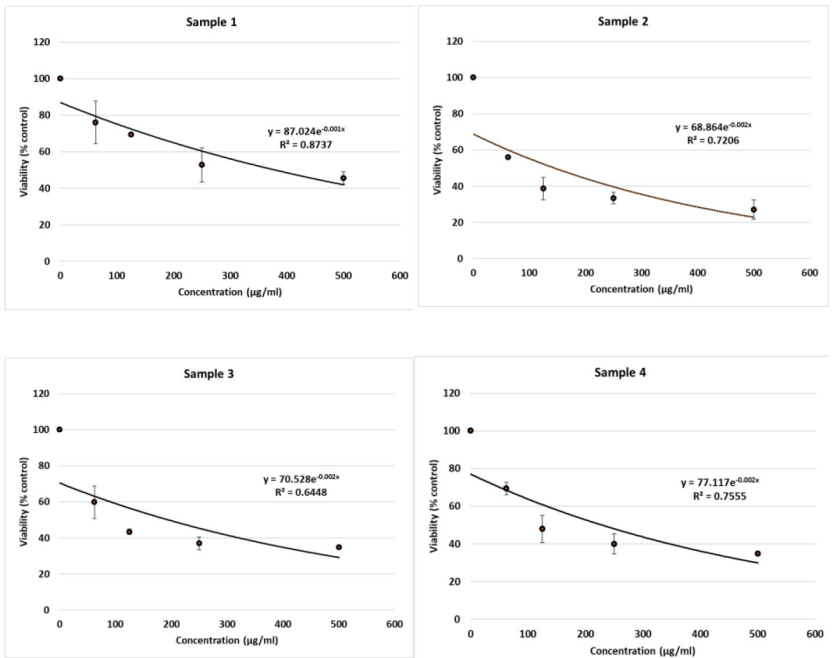

Figure 1: Cytotoxic effect of the extracts of endophytes (1-4) against Hep-G2 cell line. Results are represented as mean value $(M) \pm$ S.E.M of at least three independent experiments (3 replica each).
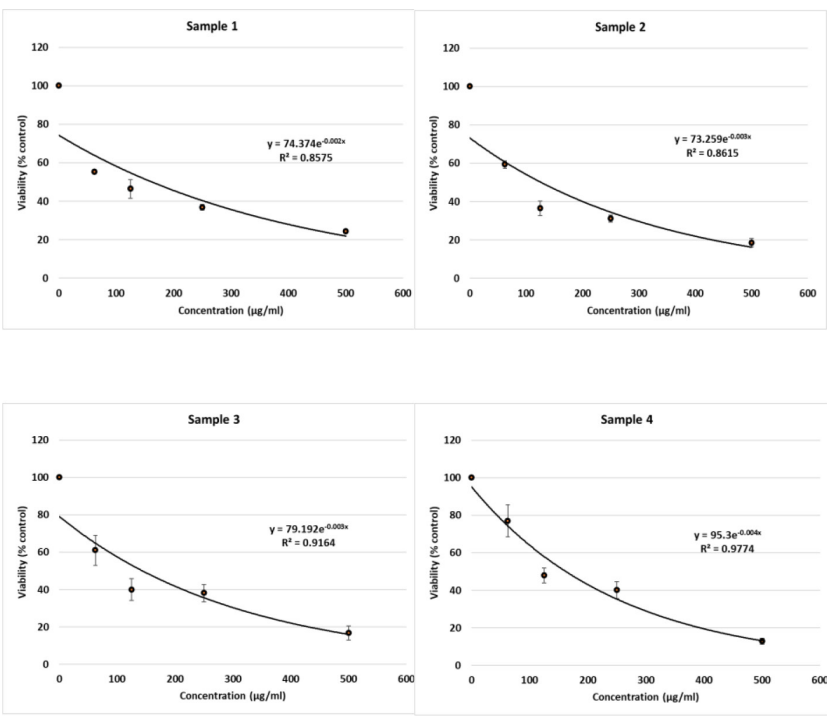

Figure 2: Cytotoxic effect of the extracts of endophytes (1-4) against T47-D cell line. Results are represented as mean value (M) \pm S.E.M of at least three independent experiments (3 replica each).
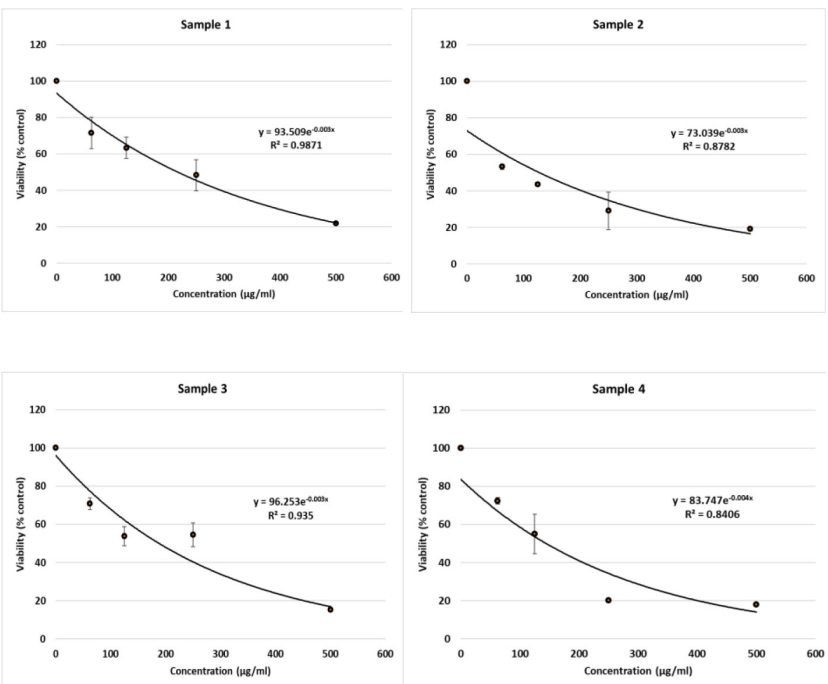

Figure 3: Cytotoxic effect of the extracts of endophytes (1-4) against HCT-116 cell line. Results are represented as mean value $(M) \pm S . E . M$ of at least three independent experiments (3 replica each).

Sample 2, on the contrary, showed highest cytotoxic activity with an $\mathrm{IC}_{50}$ value of $42 \mu \mathrm{g} / \mathrm{ml}$ against the cancer cell line HCT-116, while samples 4, 3 and 1 exhibited lower cytotoxic effects against this cell line with $\mathrm{IC}_{50}$ values of 160,212 and $243 \mu \mathrm{g} / \mathrm{ml}$ recorded for them, respectively (Figure 3).

All samples showed very close and weak cytotoxic activities against the cell line RAW 264.7 with $\mathrm{IC}_{50}$ values of $357,347,345$ and $420 \mu \mathrm{g} / \mathrm{ml}$ for samples 1, 2, 3 and 4 respectively (Figure 4). A comparison between the obtained $\mathrm{IC}_{50}$ values of the four samples on the four cell lines is shown in Figure 5. 


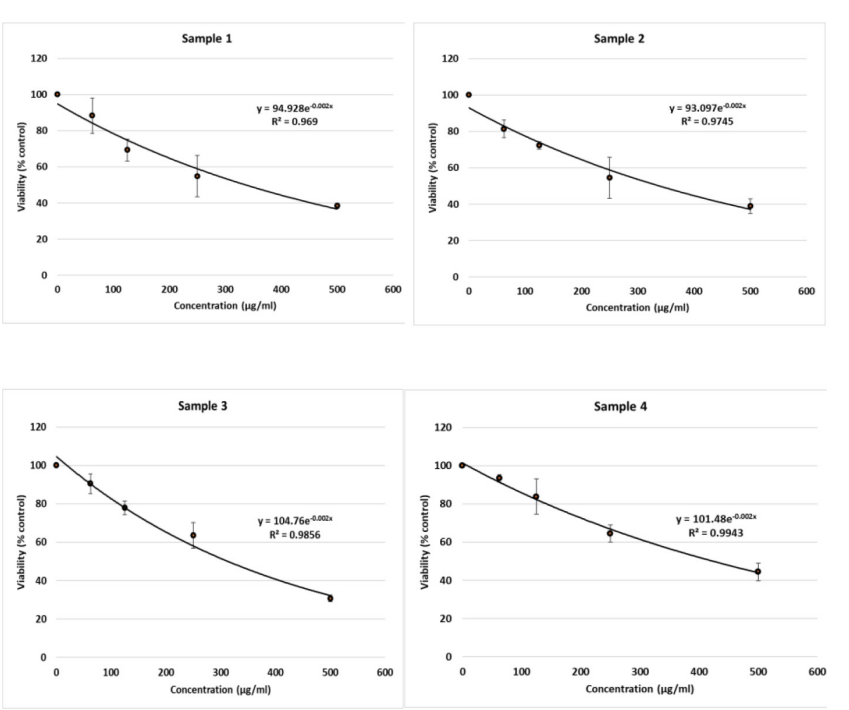

Figure 4: Cytotoxic effect of the extracts of endophytes (1-4) against RAW-264.7 cell line. Results are represented as mean value $(M) \pm S . E . M$ of at least three independent experiments (3 replica each).

IC50 values on different cell lines

-HCT-116 $=$ T47D $=$ HepG-2 $=$ RAW264.7

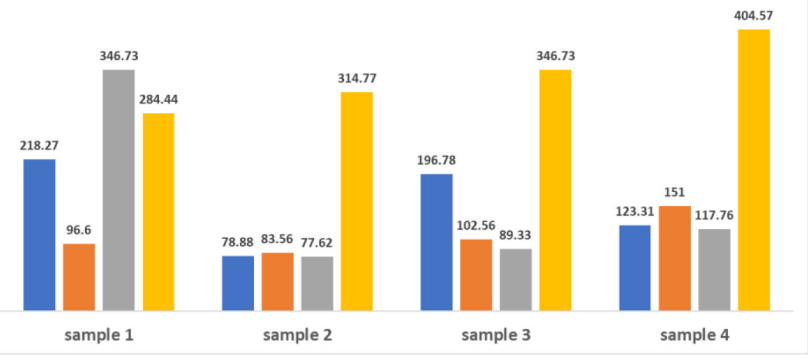

Figure 5: Different $I_{50}$ values of samples (1-4) on different cell lines.

\section{DISCUSSION}

As there is a need to explore new ecological niches with the potential of discovering bioactive natural products for pharmaceutical applications, this study has been conducted to isolate and characterize endophytes from rarely investigated plants growing in southern Saudi Arabia, which harbors a wide variety of medicinal plants. Endophytic fungi are one of the most promising groups of microorganisms that make symbiotic relationships and produce useful natural products. ${ }^{18-21}$ But many plants have not been yet investigated for their endophytic content. ${ }^{22-24}$ In our study, mainly Aspergillus and Penicillium species were isolated as endophytes of high frequency from the medicinal plants Solanum nigrum, Forsskaolea tenacissima and Calotropis procera. Different cytotoxic activities were exerted by the endophytic extracts on each cell line. These data indicate that the isolated bioactive endophytes provide promising sources of anticancer agents with therapeutic potential and are in accordance with previously published studies performed on these fungal species. A previously conducted study on Hortaea werneckii showed that it has the potential for melanin production which showed significant antibacterial effects against Vibrio parahaemolyticus and Klebsiella pneumoniae. ${ }^{25}$ Furthermore, Hortaea werneckii was previously isolated as an endophyte from the mangrove plant Acanthus ilicifolius var. xiamenensis and was shown to produce nitric oxide that contributes to the anti-inflammatory activity and high cell viability of the endophyte. ${ }^{26}$ The endophyte Penicillium solitum is an anamorph, mesophilic, salinity-tolerant and psychrotolerant species. ${ }^{27}$ The fungus Eurotium chevalieri isolated from the medicinal plant Calotropis procera occurs mainly in indoor environments and food. Five new meroterpenoids, chevalones A-D were isolated from it and exhibited antimalarial and antimycobacterial activities as well as cytotoxicity. ${ }^{28}$ Cladosporium species are often detected in indoor and outdoor environments, spoiled organic matter, are regarded as food toxicants ${ }^{29}$ and can grow even on glass fiber surfaces and water pipes. ${ }^{30}$ Many species of Cladosporium were reported to produce antimicrobial agents $^{31}$ and are effective biological insecticides, especially against those insects that have acquired resistance against chemical insecticides. ${ }^{32}$

Several studies have indicated that medicinal plants have a higher possibility of hosting endophytes that produce pharmacologically active natural products. ${ }^{33}$ Therefore, it makes sense to refer specific medicinal properties of plants to their harbored endophytes. ${ }^{19}$ Scientific literature infers that natural bioactive compounds derived from endophytes may provide an alternate source for the discovery of novel anticancer agents. ${ }^{34}$ Isolation and screening of natural bioactive compounds for pharmacological properties offer a route for the discovery of unique drug candidates and cytotoxic anticancer agents. ${ }^{35,36}$

\section{CONCLUSION}

This is the first report of endophytes isolation from the rare medicinal plants Calotropis procera, Solanum nigrum and Forsskaolea tenacissima growing in Najran region which have been found to exert significant cytotoxicity against several cancer cell lines. The current study shows that the above-mentioned plants possess a broad spectrum of endophytes with vital biological activities. Thus, collective efforts should be taken up for bioprospecting the rare medicinal plants found in this region, to preserve the microbial resources of this vital biodiversity. 


\section{ACKNOWLEDGEMENT}

We are grateful to the Deanship of Scientific Research, Najran University, for providing the funding to perform this project (NU/MID/17/062).

\section{CONFLICT OF INTEREST}

The authors have no conflicts of interest to declare.

\section{ABBREVIATIONS}

PDA: Potato dextrose agar; $\mathbf{M g S O}_{4}$ : Magnesium sulphate; HepG2: Human liver cancer cell line; HCT-116: Human colon cancer cell line; T-47D: Human ductal breast epithelial tumour cells; RAW 264.7: Raw murine macrophages; MTT: (3- (4,5-dimethyl thiazol -2-yl)-2,5-di phenyl tetrazolium bromide; DMEM: Dulbecco's Modified Eagle's Medium; $\mathbf{C O}_{2}$ : Carbon dioxide; EDTA: Ethylenediaminetetraacetic Acid; DMSO: Dimethyl sulfoxide; IC $_{50}$ : concentration inhibiting $50 \%$ of growth.

\section{SUMMARY}

In order to find new sources of anticancer agents, endophytes of the medicinal plants Calotropis procera, Solanum nigrum and Forsskaolea tenacissima growing in one of the richest areas of plant biodiversity in KSA, Najran, were investigated. Twelve endophytic fungi were isolated from the selected medicinal plants and four of them (Cladosporium herbarum (1), Hortaea werneckii (2), Penicillium solitum (3) and Eurotium chevalieri (4)) were found to exert cytotoxic activity against HepG2, T-47D, HCT-116 and RAW 264.7 cell lines in the MTT cell viability assay. Highest cytotoxicity was observed for Penicillium solitum extract on HepG2 and HCT-116 cell lines with $\mathrm{IC}_{50}$ values of $13 \mu \mathrm{g} / \mathrm{ml}$ and $42 \mu \mathrm{g} / \mathrm{ml}$, respectively. All endophytic extracts showed rather weak cytotoxic effects against RAW 264.7 cell line with $\mathrm{IC}_{50}$ values of 357,347 , 345 and $420 \mu \mathrm{g} / \mathrm{ml}$ for extracts of endophytes 1,2,3 and 4 , respectively. High cytotoxic effects were observed for the extracts of endophytes 1, 2, and 3 against T-47D cell line with $\mathrm{IC}_{50}$ values of 78,69 and $94 \mu \mathrm{g} / \mathrm{ml}$, respectively. Accordingly, these results indicate the presence of a rich source of bioactive endophytic fungi in the selected area and provides candidates for future investigation of anticancer metabolites with potential therapeutic applications.

\section{REFERENCES}

1. Ibrahim EM. Frontline gefitinib in advanced non-small cell lung cancer: metaanalysis of published randomized trials. Ann Thorac Med. 2010;5(3):153-60. doi: 10.4103/1817-1737.65047, PMID 20835310.
2. Tan RX, Zou WX. Endophytes: a rich source of functional metabolites. Nat Prod Rep. 2001;18(4):448-59. doi: 10.1039/b100918o, PMID 11548053.

3. Clay K, Schardl C. Evolutionary origins and ecological consequences of endophyte symbiosis with grasses. Am Nat. 2002;160;Suppl 4:S99-S127. doi: 10.1086/342161, PMID 18707456.

4. Strobel NE, Ji C, Gopalan S, Kuc JA, He SY. Induction of systemic acquired resistance in cucumber by Pseudomonas syringae pv. syringae $61 \mathrm{HrpZPsS}$ protein. Plant J. 1996;9(4):431-9. doi: 10.1046/j.1365-313X.1996.09040431.x.

5. Nagi HM, Abubakr MM. Threats status to the mangrove ecosystem along the coastal zone of yemen. JKAU: Mar Sci. 2013;24(1):101-17. doi: 10.4197/ Mar.24-1.8.

6. Silva MCC, Silva ABd, Teixeira FM, Sousa PCPd, Rondon RMM, Júnior JERH, et al. Therapeutic and biological activities of Calotropis procera (Ait.) R.Br. Asian Pacific. J Trop Med. 2010:332-6.

7. Kaushik D, Jogpal V, Kaushik P, LS, Saneja A, Sharma C, et al. Evaluation of activities of Solanum nigrum fruit extract. Arch Appl Sci Res. 2009;1(1):43-50.

8. Hamdy KA, Alaa MN, Mohamed SA, Ahmed EA. KMS. Phytochemical and biological studies of aerial parts of Forsskaolea tenacissima Linn. (Urticaceae). J Pharmacogn Phytochem. 2015;4(3):282-90.

9. Abdou R. Bioactive metabolites from the endophyte Botryosphaeria obtuse of the medicinal plant Bidens pilosa. Int J Pharm Pharm Sci. 2013;5(3):09751491.

10. Abdou R, Alqahtani AM, HAG. Bioactive metabolites of Aspergillus neoniger, an endophyte of the medicinal plant Ficus carica. Indian J Pharm Sci. 2021;83(1):101-9.

11. Abdou R, Shabana S, Rateb ME. Terezine E, Bioactive prenylated tryptophan analogue from an endophyte of Centaurea stoebe. Nat Prod Res. 2020;34(4):503-10. doi: 10.1080/14786419.2018.1489393, PMID 30092665.

12. Barnett $\mathrm{HL}, \mathrm{BBH}$. Illustrated genera of imperfect fungi. APS press St Paul Minneesota USA. 1998.

13. Chougule PM, Andoji YS. Isolation and frequency distribution of endophytic fungi inhabiting. Justicia Adhatoda L. RJLBPCS. 2015;1(4).

14. Raviraja NS, Maria GL, Sridhar KR. Antimicrobial evaluation of endophytic fungi inhabiting medicinal plants of the Western Ghats of India. Eng Life Sci. 2006;6(5):515-20. doi: 10.1002/elsc.200620145.

15. Hansen MB, Nielsen SE, Berg K. Re-examination and further development of a precise and rapid dye method for measuring cell growth/cell kill. J Immunol Methods. 1989;119(2):203-10. doi: 10.1016/0022-1759(89)90397-9, PMID 2470825.

16. Aly AA, Brown AB, Ramadan M, Gamal-Eldeen AM, Abdel-Aziz M, AbuoRahma Gel-D, Radwan MF. Thieno[2,3-d]pyrimidines in the synthesis of antitumor and antioxidant agents. Arch Pharm (Weinheim). 2010;343(5):301-9. doi: 10.1002/ardp.200900245, PMID 20232374.

17. Grizzle HW, Zak JC. A microtiter plate procedure for evaluating fungal functional diversity on nitrogen substrates. Mycologia. 2006;98(2):353-63. doi: 10.3852/mycologia.98.2.353, PMID 16894979.

18. Singh MP. Application of Biolog FF microplate for substrate utilization and metabolite profiling of closely related fungi. J Microbiol Methods. 2009;77(1):102-8. doi: 10.1016/j.mimet.2009.01.014, PMID 19318055.

19. Zhao K, Penttinen P, Guan T, Xiao J, Chen Q, Xu J, Lindström K, Zhang L, Zhang $X$, Strobel GA. The diversity and anti-microbial activity of endophytic actinomycetes isolated from medicinal plants in Panxi plateau, China. Curr Microbiol. 2011;62(1):182-90. doi: 10.1007/s00284-010-9685-3, PMID 20567975.

20. Kour D, Rana KL, Kaur T, Devi R, Negi C, Yadav AN, et al. Endophytic fungi from medicinal plants: biodiversity and biotechnological applications. Microb Endophytes. 2020:273-305.

21. Newman DJ, Cragg GM. Natural products as sources of new drugs over the nearly four decades from 01/1981 to 09/2019. J Nat Prod. 2020;83(3):770803. doi: 10.1021/acs.jnatprod.9b01285, PMID 32162523.

22. Gundel PE, Martínez-Ghersa MA, Omacini M, Cuyeu R, Pagano E, Ríos R, Ghersa CM. Mutualism effectiveness and vertical transmission of symbiotic fungal endophytes in response to host genetic background. Evol Appl. 2012;5(8):838-49. doi: 10.1111/j.1752-4571.2012.00261.x, PMID 23346228.

23. Selosse MA, Schardl CL. Fungal endophytes of grasses: hybrids rescued by vertical transmission? An evolutionary perspective. New Phytol. 2007;173(3):452-8. doi: 10.1111/j.1469-8137.2007.01978.x, PMID 17244040. 
24. Fröhlich J, Hyde KD. Biodiversity of palm fungi in the tropics: are global fungal diversity estimates realistic? Biodivers Conserv. 1999;8(7):977-1004. doi: 10.1023/A:1008895913857.

25. Rani M, Ramesh T, Subramanian J, MK. Production and characterization of melanin pigment from halophilic black yeast Hortaea werneckii. Int J Pharm Res Rev. 2013;2(8):9-17.

26. Chi WC, Pang KL, Chen WL, Wang GJ, Lee TH. Antimicrobial and iNOS inhibitory activities of the endophytic fungi isolated from the mangrove plant Acanthus ilicifolius var. xiamenensis. Bot Stud. 2019;60(1):4. doi: 10.1186/ s40529-019-0252-3, PMID 30868333.

27. De Hoog GS, Guarro J, Gené J, MJF. Atlas of clinical fungi. Centraalbureau voor Schimmelcultures (CBS); 2000.

28. Kanokmedhakul K, Kanokmedhakul S, Suwannatrai R, Soytong K, Prabpai S, Kongsaeree P. Bioactive meroterpenoids and alkaloids from the fungus eurotium chevalieri. Tetrahedron. 2011;67(30):5461-8. doi: 10.1016/j. tet.2011.05.066

29. Dixon DM, Polak-Wyss A. The medically important dematiaceous fungi and their identification. Mycoses. 1991;34(1-2):1-18. doi: 10.1111/j.14390507.1991.tb00613.x, PMID 1922184.

30. Johanning E, Landsbergis P, Gareis M, Yang CS, Olmsted E. Clinical experience and results of a Sentinel Health Investigation related to indoor fungal exposure. Environ Health Perspect. 1999;107(3);Suppl 3:489-94. doi: 10.1289/ehp.99107s3489, PMID 10346997.

31. Sinsabaugh RL, Zak DR, Gallo MLC, Lauber C, Amonette R. Nitrogen deposition and dissolved organic carbon production in northern temperate forests. Soil Biol Biochem. 2004;36(9):1509-15. doi: 10.1016/j. soilbio.2004.04.026.

32. Abdel-Baky NF, Abdel-Salam AH. Natural incidence of Cladosporium spp. as a bio-control agent against whiteflies and aphids in Egypt. J Appl Entomology. 2003;127(4):228-35. doi: 10.1046/j.1439-0418.2003.00662.x.

33. Strobel G, Daisy B, Castillo $U$, Harper J. Natural products from endophytic microorganisms. J Nat Prod. 2004;67(2):257-68. doi: 10.1021/np030397v, PMID 14987067.

34. Xie S, Zhou J. Harnessing plant biodiversity for the discovery of novel anticancer drugs targeting microtubules. Front Plant Sci. 2017;8:720. doi: 10.3389/fpls.2017.00720, PMID 28523014.

35. Salvador-Reyes LA, Luesch H. Biological targets and mechanisms of action of natural products from marine cyanobacteria. Nat Prod Rep. 2015;32(3):478503. doi: 10.1039/c4np00104d, PMID 25571978.

36. Stierle AA, Stierle DB. Bioactive secondary metabolites produced by the fungal endophytes of conifers. Nat Prod Commun. 2015;10(10):1671-82. doi: 10.1177/1934578X1501001012, PMID 26669101.

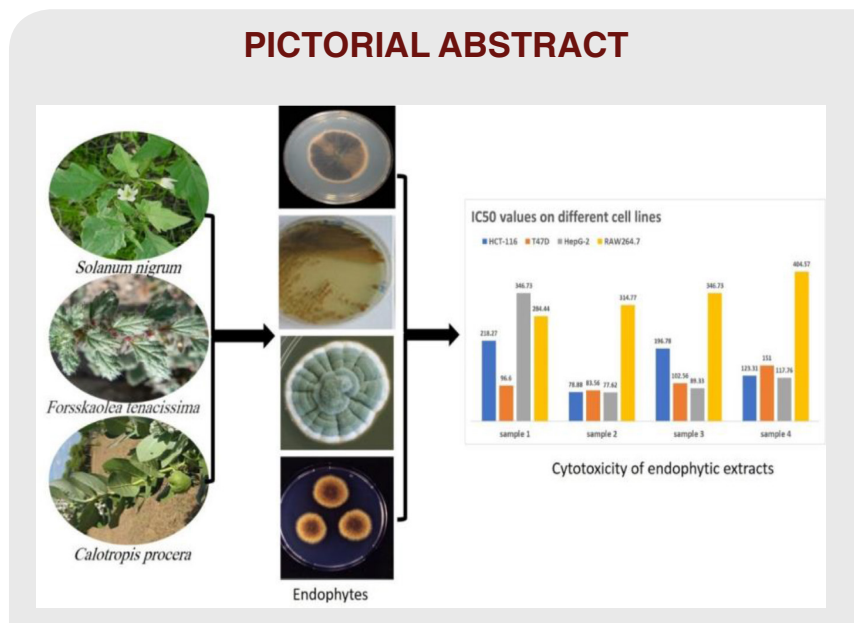

About Authors

Ass. Prof. Dr. Hany Gouda Attia Ph.D in Pharmacognosy, Faculty of Pharmacy, Helwan University (2011) Current position: Ass. Prof. of Pharmacognosy, College of Pharmacy, Najran University, Saudi Arabia.

Ass. Prof. Dr. Mohamed Aleraky. Ph.D in clinical pathology, College of Medicine, Alazhar University, Egypt (2006) Current position: Head of the Department of Clinical Pathology, College of Medicine, Najran University, Saudi Arabia.

\section{SUMMARY}

In order to find new sources of anticancer agents, endophytes of the medicinal plants Calotropis procera, Solanum nigrum and Forsskaolea tenacissima growing in one of the richest areas of plant biodiversity in KSA, Najran, were investigated. Twelve endophytic fungi were isolated from the selected medicinal plants and four of them (Cladosporium herbarum (1), Hortaea werneckii (2), Penicillium solitum (3) and Eurotium chevalieri (4)) were found to exert cytotoxic activity against HepG2, T-47D, HCT-116 and RAW 264.7 cell lines in the MTT cell viability assay. Highest cytotoxicity was observed for Penicillium solitum extract on HepG2 and HCT116 cell lines with $\mathrm{IC}_{50}$ values of $13 \mu \mathrm{g} / \mathrm{ml}$ and $42 \mu \mathrm{g} /$ $\mathrm{ml}$, respectively. All endophytic extracts showed rather weak cytotoxic effects against RAW 264.7 cell line with $\mathrm{IC}_{50}$ values of $357,347,345$ and $420 \mu \mathrm{g} / \mathrm{ml}$ for extracts of endophytes 1,2,3 and 4, respectively. High cytotoxic effects were observed for the extracts of endophytes 1,2 , and 3 against T-47D cell line with $\mathrm{IC}_{50}$ values of 78,69 and $94 \mu \mathrm{g} / \mathrm{ml}$, respectively. Accordingly, these results indicate the presence of a rich source of bioactive endophytic fungi in the selected area and provides candidates for future investigation of anticancer metabolites with potential therapeutic applications. 
Prof. Dr. Mahmoud Youns Ph.D in Biochemistry, German Cancer Research Center, Heidelberg University (2009). Current position: Prof. of Biochemistry and Molecular biology, Faculty of Pharmacy, Helwan University, Egypt.

Dr. Randa Abdou Ph.D in Pharmacognosy, Friedrich Schiller University, Jena, Germany (2011). Current position: Ass. Prof of Pharmacognosy, Faculty of Pharmacy, Umm Al-Qura University, Makkah, Saudi Arabia.

Cite this article: Attia GH, Aleraky M, Youns M, Abdou R. Cytotoxicity of Endophytes of Calotropis procera, Solanum nigrum and Forsskaolea tenacissima. Indian J of Pharmaceutical Education and Research. 2021;55(3):872-9. 